\title{
ENGINE LOW PERFORMANCE CAUSED BY DIESEL BS 500
}

\author{
Sergio Roberto Amaral ${ }^{1}$, Ricardo Alexandre Sassa ${ }^{2}$, Fabio Novaes Limeira ${ }^{3}$, Rogério Curty \\ Dias $^{4}$, Rafael Sorgini Manfredi ${ }^{5}$, Marcos Marcondes ${ }^{6}$ \\ Volkswagen Truck \& Bus ${ }^{1}$ \\ Volkswagen Truck \& Bus ${ }^{2}$ \\ Volkswagen Truck \& Bus ${ }^{3}$ \\ Volkswagen Truck \& Bus ${ }^{4}$ \\ $\mathrm{IAV}^{5}$ \\ TECCOM $^{6}$
}

Sergio.amaral@volkswagen.com.br, ricardo.sassa@ volkswagen.com.br, foafio.limeira@volkswagen.com.br, rogerio.dias@ volkswagen.com.br, rafael.mandredi@iav.de, mmarcondes@ teccom10.com.br

\begin{abstract}
Nowadays in some Brazilian regions the fuel available to the customer has $500 \mathrm{ppm}$ of Sulphur with currently biodiesel percentage (B7 and from march'17 on B8) defined by Petroleum, Natural Gas and Biofuels National Agency (ANP) and after nearly 6 years of Euro $\mathrm{V}$ implemented in Brazil the fuel distributor has no time to phase out of this diesel in order to distribute only Low Sulphur Diesel BS 10. Currently it's necessary to validate all vehicles with Diesel BS 500 in order to be sold to Brazilian North Region customers. We could confirm main filter with low performance and also fuel injector's failure as a consequence of low performance indication. All injectors were evaluated and we could confirm deposits due to high temperature and contamination that avoid the diesel spray inside engine combustion chamber. Analyzing all fuel lines and filters (pre filter and main filter) housing and it was possible to find out organic contamination after one week of all components replaced. Evaluating diesel from main tank and durability vehicles tanks, the results have shown property losses after one week of fuel usage. It was evaluated the results of low oxidation stability according to Rancimat modified (EN 15751:2014) analysis methodology and check the relation with vehicle performance lost.
\end{abstract}

\section{INTRODUCTION}

According to ANP Management Bulletin 53 in December' 16 the market share regarding BS 500 represents $66,7 \%$ of all diesel distributed in the Brazilian Market (see graphic 1). In order to attend the Euro V Emissions requirements the engines must be validate with worst diesel distributed. Then, durability has been done by Engineering Area evaluating performance, fuel consumption and fuel system components specially injectors. The comparison between BS 10 as usual test requirement that assure same conditions for engine approval. In November'2014 the biodiesel percentage was changed from 5\% to 7\% and from 7\% to 8\% in March'2017 according to the Law 13263/16. During engine validation tests started in October'2016, it was 
verified that the vehicle had lost performance. Some evaluations were done at fuel filters (pre filter and main filter), injectors and fuel. After deep analysis it was identified the Diesel was the root cause of the vehicle low performance.

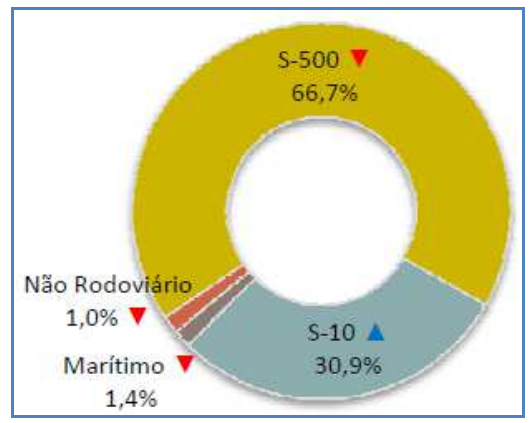

Grahic 1. The graphic represents the percentage of total fuel distributed in Brazil in 2016, according to ANP (see http:///www.anp.gov.br).

\section{1 - ENGINEERING TEST - COMPONENTS EVALUATION}

The methodology used when few engine modification were done is variation speed between 0 $\mathrm{km} / \mathrm{h}$ to $90 \mathrm{~km} / \mathrm{h}, 0 \mathrm{~km} / \mathrm{h}$ to $80 \mathrm{~km} / \mathrm{h}$, measure speed recovery between $20 \mathrm{~km} / \mathrm{h}$ to $40 \mathrm{~km} / \mathrm{h}$, $20 \mathrm{~km} / \mathrm{h}$ to $60 \mathrm{~km} / \mathrm{h}$ and the data in average are compared to the standard vehicle model. Tests regarding an uphill and downhill are done as well. All tests were done with instrumented vehicle and all data are evaluated graphically. Then, it was analyzed if the vehicle keeps the same vehicle standard level or not. This analysis model evaluates the fuel consumption, performance, torque/power, speed recovery and top speed after all information compiled is decided the next steps or actions. Test in ramp is used for a quick evaluation regards an engine performance in order to compare and assure de uphill data.

\section{2 - VEHICLE PERFORMANCE LOSS}

During the engineering development test with Diesel BS500 it was detected a performance losses after $2300 \mathrm{~km}$. It was evaluated at the beginning the fuel injectors. The result shows overheat in three of six the injector nozzles (see picture 1). Then, was decided to replace all injectors and restart the tests. After running $1500 \mathrm{~km}$ new performance losses happened and the injectors were analyzed again. The injector's analysis results shows overheat and contaminations (see picture 2).
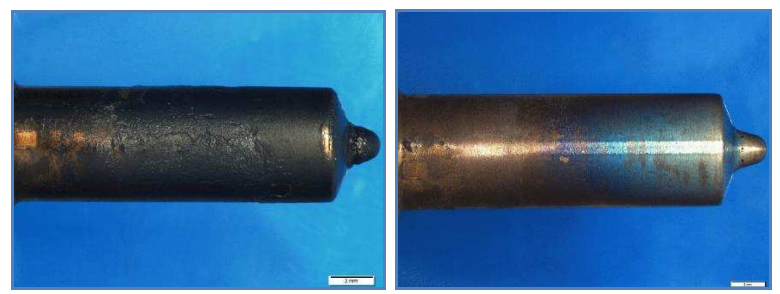
Picture 1. The picture shows the injector nozzle \#5 after $2300 \mathrm{~km}$ tested before and after cleaned. The results inform overheat and contamination.
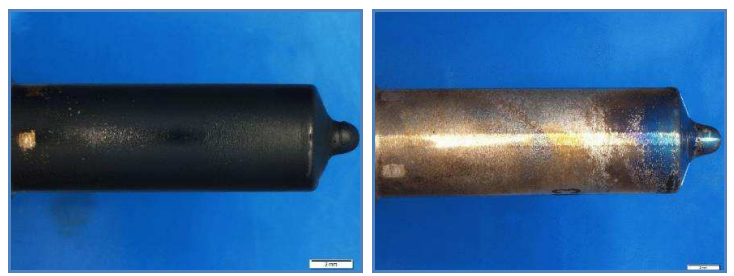

Picture 2. The picture shows the injector nozzle \#3 after $1500 \mathrm{~km}$ tested before and after cleaned. The results inform overheat and contamination

\section{3 - ENGINEERING ANALYSIS}

In order to discover the root failure cause, was prepared a Fault Tree Analysis (FTA) identifying possible causes and investigating each one. Using the Markov's Model (see picture 3) which includes the most probable cause and secondary probable cause. In order to evaluate the injector malfunction it was evaluated fuel line return back pressure, fuel system dirty, injector degradation, exhaust brake back pressure and diesel quality.

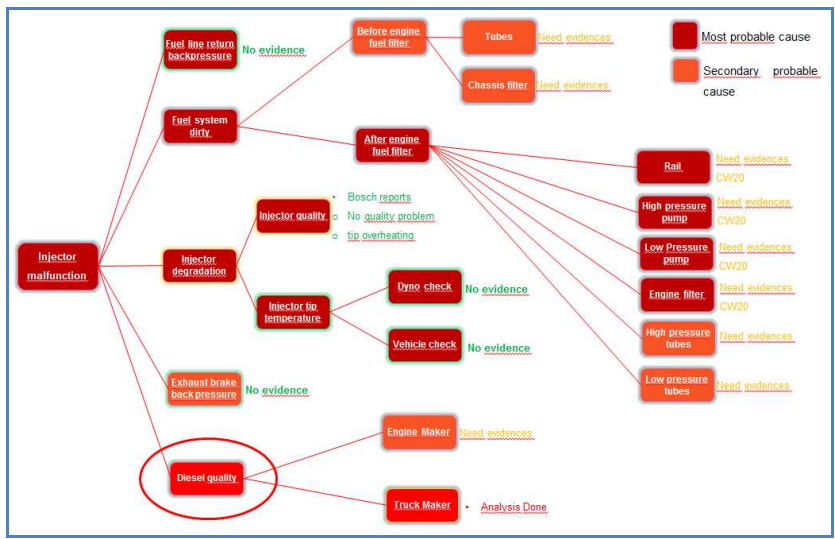

Picture 3. FTA used to identify the root cause of failure. It was used a Markov Model

The failure timeline was done in order to keep easy to follow the sequence of occurrences during the highway durability test (see picture 4).

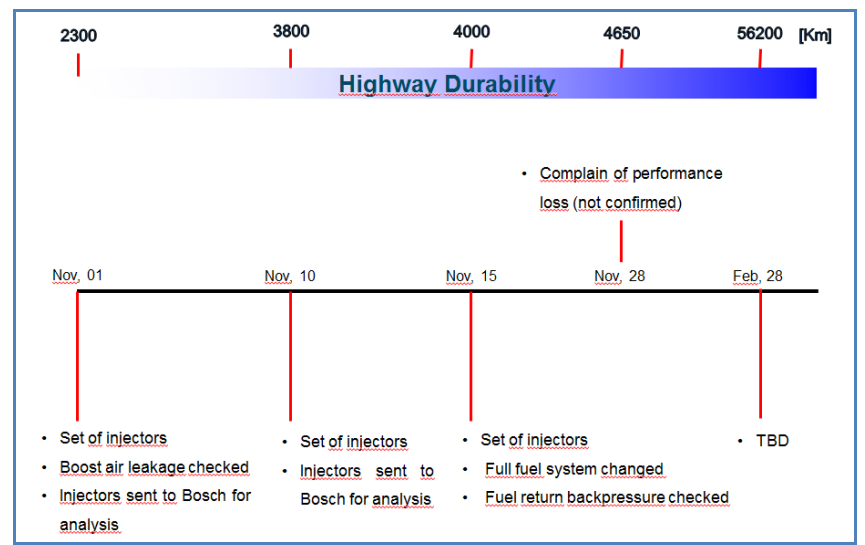


Picture 4. The picture shows the failure timeline with mileage for each failure, parts replaced and analysis definition.

The two sets replaced according to timeline in $1^{\text {st }}$ Nov' 16 and $10^{\text {th }}$ Nov' 16 were evaluated and the results show reduction flow in 3 nozzles at first replaced set (see table 1) and all nozzles at second set and excessive temperature (see table 2).

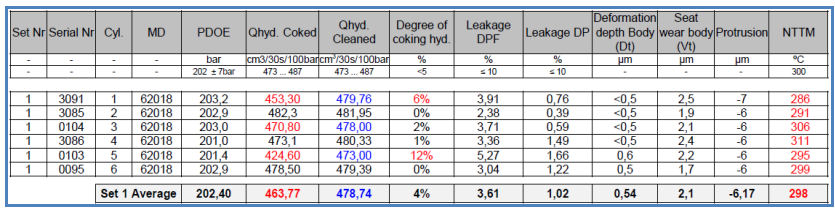

Table 1. The table shows the results of injector nozzles from set one with flow reduced at injector nozzles 1, 3 and 5.

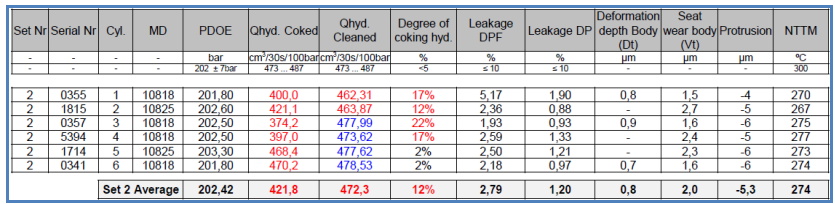

Table 2. The table shows the results of injector nozzles from set two with flow reduced at all injector nozzles.

It was confirmed after the injector nozzles replaced no performance problem was detected. The vehicle was instrumented and it covers all engine data and keeps the same durability test until $56200 \mathrm{~km}$ when new performance loss was noticed. The comparison was done at ramp test with $20 \%$ of inclination and the test starts around $1000 \mathrm{rpm}$ at $3^{\text {rd }}$ gear and push full throttle and at the end of ramp must have minimum $2000 \mathrm{rpm}$. The graphic 2 represents the difference between performance ok and performance loss.

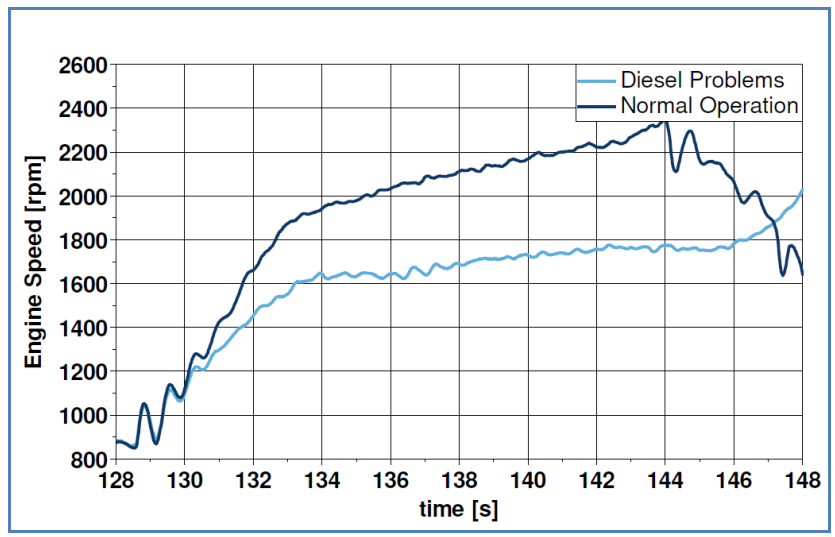

Graphic 2. The graphic shows the vehicle's performance with a normal condition and with performance loss.

After performance test done it was decided to verify the fuel appearance visually. The main fuel filter was disassembled in order to see the filtering element and it was possible to see a lot of sediments inside of the fuel housing and the new element with $6000 \mathrm{~km}$ shows sediments fixed on the element media (see picture 5). The comparison of the vehicle with the 
same $6000 \mathrm{~km}$ using the BS10, the filtering element looks totally new. The main filter was disassembled and the fuel housing looks new as well (see picture 6). The filtering element was compared with same mileage vehicle but with diesel BS 10 (see picture 7). It was decided to collect fuel from vehicle's diesel tank and it was seen a lot of sediments inside it (see picture 8).

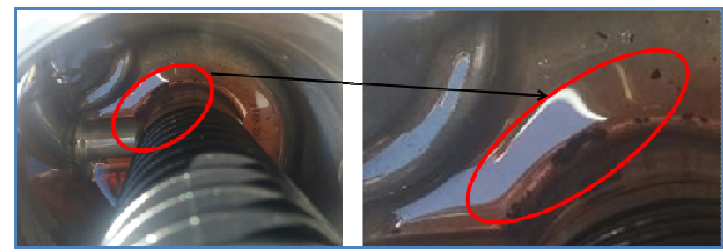

Picture 5. The picture shows sediments inside of main filter housing with Diesel BS 500.

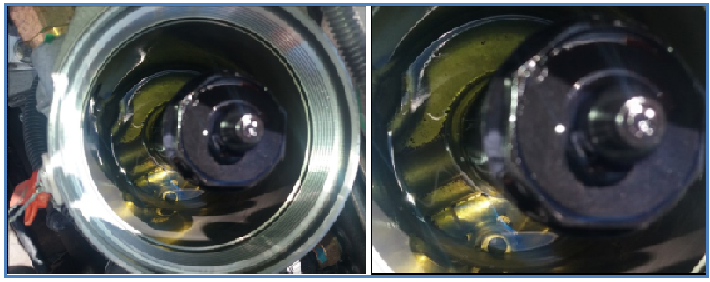

Picture 6. The picture shows normal main filter housing with Diesel BS 10.
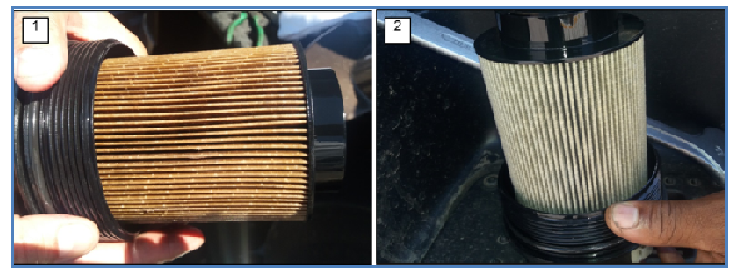

Picture 7. The picture shows: 1) Filtering element with $6000 \mathrm{~km}$ tested with BS500; 2) Filtering element with $6000 \mathrm{~km}$ tested with BS 10.

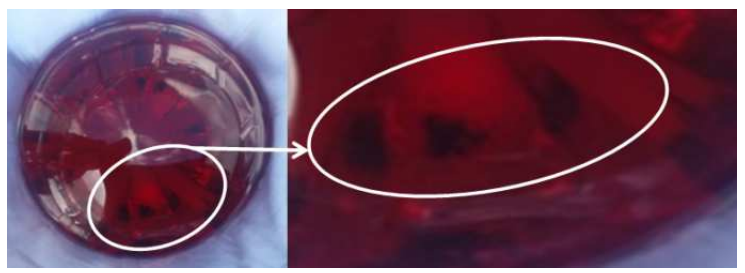

Picture 8. The picture shows sediments inside of fuel tank fueled with diesel BS 500.

\section{4 - DIESEL ANALYSIS AND RESULTS}

It was collected diesel from main tank and from vehicle's tank to send to two laboratories for analysis. The method defined was Rancimat modified EN15751:2014 "Automotive fuel acid methyl ester (FAME) fuel and blends with diesel fuel - determination of oxidation stability by accelerated oxidation method" in order to identify the oxidation stability in hours from main tank diesel. It was decided to evaluate with current product sold in market called Almax used for Diesel Stability produced by TECCOM (Industria e Comércio de Produtos Técnicos em Combustão Ltda.) and as received by fuel distributor. Based on ANP Technical Note \# 
$73 / 2014 / \mathrm{SBQ} / \mathrm{RJ}$ the minimum oxidation stability in hours to B100 (only biodiesel) is 8 hours and diesel with $7 \%$ of biodiesel must has minimum 20 hours for oxidation stability, according to ANP Resolution \#30 in June $23^{\text {th }}$ of 2016 and published at Union Official Diary (DOU) in June $27^{\text {th }}$ of 2016 using Rancimat modified method EN15751:2014. According to Researches published at International Symposium of Automotive Engineering (SIMEA/16 - PAP67 2016) the diesel was mixed with biodiesel in laboratory (with controlled condition) the Rancimat method can be used to analyze diesel blends of S10 and S500 BX (see graphic 3).

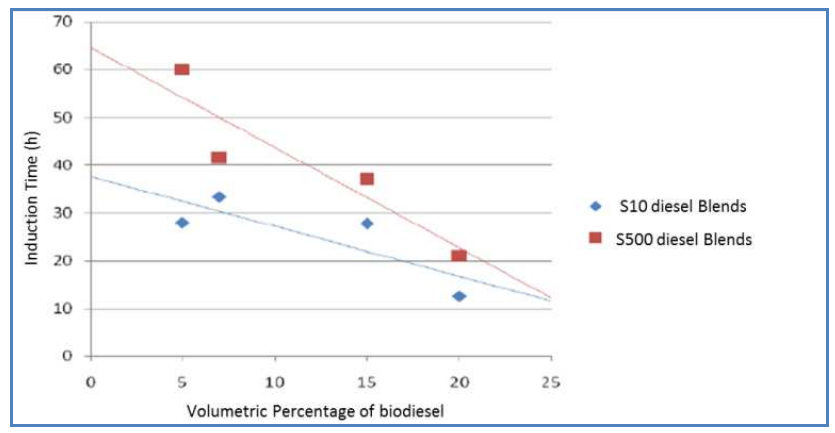

Graphic 3. The graphic shows oxidative stability at $110^{\circ} \mathrm{C}$ by Rancimat EN15751:2014 at diesel/biodiesel blends (Paper published at SIMEA/16 - PAP67-2016 - Estudos da Adição de biodiesel no diesel S10 e S500 e seus efeitos nas propriedades do combustivel e na atomização).

It is possible to understand with graphic 3 why all engine validation tests with BS 500 never show any problem at fuel system (low pressure and high pressure side) caused by biodiesel percentage up to now. The oxidation stability by Rancimat EN15751:2014 is highest than BS 10 with B7 and B8 and it's basically that no injectors nozzles failures were noticed.

The diesel samples from main tank were issued to laboratory with international certification and the results show low oxidation stability. It was added Almax additive (1:500) at main tank diesel sample in order to increase the oxidation stability and avoid engine test validation delay. It was confirmed the stability upgrade however not enough to solve the problem (see table 3).

We also send to second laboratory (Oilcheck) sample from main tank in order to confirm the oxidative stability results and sample from main tank after distributor replace all S500 for a new one.

The diesel oil replaced does not have the minimum approved by ANP regarding the oxidative stability.

\begin{tabular}{|c|c|c|c|}
\hline \multirow{2}{*}{$\begin{array}{c}\text { LACOR Sample } \\
\text { Cude (INT) }\end{array}$} & Customer Sample Code & \multicolumn{2}{|c|}{ Oxidative Stability $(\mathrm{h})$} \\
\cline { 3 - 4 } & & Results & Deviation (\%) \\
\hline 2017.0027 & S500 B7 (Main Tank) & $\mathbf{7 , 9 4}$ & 0,62 \\
\hline 2017.0028 & S500 B7 + Almax (Maln Tank) & $\mathbf{1 7 , 1 5}$ & $\mathbf{0 , 5 8}$ \\
\hline
\end{tabular}

Table 3. The table shows the National Technology Institute (INT) laboratory results for Oxidative Stability by EN15751:2014 method with diesel as received from Brazilian distributor and same diesel with Almax additive.

\begin{tabular}{|c|c|c|}
\hline $\begin{array}{c}\text { LEC Sample Code } \\
\text { (Olicheck) }\end{array}$ & Customer Sample Code & Oxidative Stability (h) \\
\cline { 3 - 3 } & & Results \\
\hline $336 / 17-B$ & S500 B7 (Maln Tank) & 8,9 \\
\hline $335 / 17$ - B & S500 B7 (Main Tank replaced) & 16,5 \\
\hline
\end{tabular}


Table 4. The table shows the Oilcheck Laboratory results for Oxidative Stability by EN15751:2014 method with diesel as received from Brazilian distributor and after replaced by distributor.

\section{5 - CONCLUSIONS}

After evaluate the possibilities described at Markov's FTA model, it is possible to conclude that the diesel BS500 received from Brazilian distributor has very low oxidative stability and that is the root probable cause and this condition add a thermal condition speed up the oxidation process forming agglomeration and nucleation. The thermal conditions probably make the migration and adherence at injector's nozzles surfacing forming deposits in a very short time.

The Almax additive could increase the oxidative stability more than $100 \%$, but above the minimum approved by ANP $(20 \mathrm{~h})$. However the Almax could be a solution for field application adding the proportion 1:500 at fuel tanks at the moment as fueled in order to reduce the thermal condition and agglomeration formation at injector's nozzles avoiding engine performance loss and parts replacement in field.

A new main tank fuel was replaced from the current distributor and the failure does not appear anymore, according to the Table 3 . The conclusion is that low oxidative stability is the root cause of premature engine performance loss. Probably the thermodynamic boundaries (temperature and pressure) plus diesel with 7\% of biodiesel (BS500) compounds could speed up the oxidative reaction reducing the injector nozzle flow and increase its temperature making the overheating informed at supplier analysis. The same problem probably will reoccur with percentages over B7 caused by low stability.

\section{REFERENCES}

[1] BRUNETTI, FRANCO. Motores de Combustão Interna, Ed. Blucher - 2012, volume 1, p. $351-400$

[2] EN 15751, Automotive Fuels, Fatty Acid Methyl Ester (FAME) Fuel and blends with Diesel Fuel - Determination of Oxidation Stability by Accelerated Oxidation Method.

[3] Portaria $N^{\circ} 80$ de 02 de Março de 2017 - Publicada no diário Oficial da União (DOU) em 03/03/2017. Available at:

www.lex.com.br/legis_27316938_PORTARIA_N_80_DE_2_DE_MARCO_DE_2017; access in: 03/03/2017.

[4] FARIA, M.D.C; PINTO, R.R.C.; VALLE, M.L.M., Efeito do Biodiesel na Atomização do Combustível em Motores Diesel de Injeção Direta, Revista de Química Industrial, $2^{\circ}$. Trimestre de 2010.

[5] HIGGINS, B. S.; MUELLER, C. J.; SIEBERS, D. L. Measurements of fuel effects on liquid-phase penetrations in DI sprays. Detroit: Society of Automotive Engineers - SAE Technical Papers Series 1999-01-0519, 1999.

[6] ALlOCA, L.; CORCIONE, F.E; COSTA, M. Numerical and experimental analysis of multiple injection diesel sprays. França: Society of Automotive Engineers, SAE Technical Papers Series 2004-01-1879, 2004. 
[7] BERThiaume, D.; TREMBlay, A.; Study of the Rancimat Test Method in Measuring the Oxidation Stability of Biodiesel Ester and Blends. Oleotek Inc., NRCan project CO414 CETC-327, 2006.

[8] ELKOBT, M.M. Fuel atomization for spray modeling. Progress in Energy Combustion Science.Great Britain, v.8 p. 61-91, 1982.

[9] RESOLUÇÃO ANP no 45 de 25/08/2014. Disponível em http://www.anp.gov.br. Access in: 16/02/2017.

[10] RESOLUÇÃO ANP n ${ }^{\circ} 51$ de 25/11/2015. Disponível em http://www.anp.gov.br. Access in: $16 / 02 / 2017$.

[11] CARVALHO, Roberta de Almeida; TEIXEIRA, Roberta M.; VALLE, Maria Letícia Murta; "Estudo da adição de biodiesel no diesel s10 e s500 e seus efeitos nas propriedades do combustível e na atomização", p. 427-446 . In: Anais do XXIV Simpósio Internacional de Engenharia Automotiva - SIMEA 2016 [=Blucher Engineering Proceedings].. $\quad$ São $\quad$ Paulo: 2016. ISSN 2357-7592,
DOI 10.5151/engpro-simea2016-PAP67 ISBN: 